\title{
2船並走時の舵と船体の流体力学的干渉に及ぼす浅水影響
}

\author{
佐野 将昭 ${ }^{1}$ 安川 宏紀 1 吉田 聖子 $^{2}$
}

\section{Shallow Water Effect on Hull to Rudder Interactions between Two Ships Alongside}

\section{Masaaki SANO, Hironori YASUKAWA and Seiko YOSHIDA}

\begin{abstract}
Ship is under way side by side in close proximity to the other ship in the case of meeting/overtaking in a narrow waterway or ship to ship transfer operation. Since it is required to understand the hydrodynamic force characteristics for safe navigation, a lot of studies on them have been done so far. However there have been few studies on the hull to rudder interactions between two ships alongside except for the previous study by authors. ${ }^{1)}$

This study is a continuous work and the shallow water effect on them is discussed. Captive model tests were conducted in shallow water, i.e. the depth/draft ratio 1.2 and 1.5, with variations in the lateral clearance between hulls, hull drift angle and rudder angle. The authors found, for example, when a ship steered, the lift interaction force acted not only on the self-ship but also on the other ship moving side by side in close proximity. It turned in the opposite direction and its acting point was also shifted with decrease of water depth. The experimental results were compared with the numerical analysis based on a nonlinear lifting body theory and it was able to capture the tendency of the shallow water effect on those hydrodynamic force characteristics.
\end{abstract}

Keywords : Two ships, Hydrodynamic interaction, Shallow water effect, Steering, Oblique towing キーワード: 2 船, 流体力学的干涉, 浅水影響, 操舵, 斜航

\section{1. 緒言}

\section{1 背景と目的}

2 船並走時の相互干渉問題は、航行の安全上、古 くから重要なテーマとして注目されてきた。しかし これまで船体間の相互干渉を研究した例 ${ }^{23) 4}$ (4多数 あっても、2 船の舵と船体の干渉という観点から検

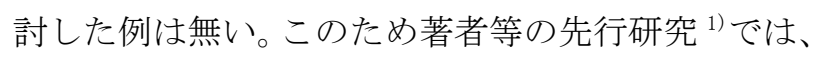
深水域において、1 隻の船が操舵・斜航しながら他 の船の傍を並走する状況を想定し、2 船の舵と船体 間に起こる流体力学的干渉について基礎的な検討を 行った。その成果の一つに、操舵による干渉影響が、 舵をとった側の船の船体のみならず、近くを並走す る船にもおよび、その船尾付近に付加流体力を発生 させる事を示した。この状況は、洋上荷役オペレー
ション時の接舷・離舷操船を念頭においたものであ ったが、同様の観点から浅水域での干渉問題を考察 する事は、狭水路における行き会いや追い越し時な ご、船舶同士が接近せざるを得ない操船局面でも役 立つと思われる。

1 隻の場合の舵と船体間の流体力学的干渉に及ぼ す浅水影響の検討例としては、藤野等の非線形揚力 面理論に基づく研究 ${ }^{5)}$ が挙げられ、操舵によって船 体に誘起される付加流体力が、水深の減少に伴い顕 著に増加する事が示されている。この為、同様のメ カニズムで発生する 2 船並走時の舵と船体の流体力 学的干渉もまた浅水影響を受けて変化すると考える べきであり、場合によっては、1 隻の船が舵を取る と、近くを走る船に大きな付加流体力が働く事態も 
考えられる。

そこで本研究では、過去に知見が無い同干渉作用 に及ぼす浅水影響を実験により明らかとする事を目 的とする。併せて理論計算結果を示す事で実験点を 補間すると共に、各船体に生じる循環の強さ・向き を考察して現象の理解に役立てる。加えて今回は、1 隻が斜航する状況の実験も行っており、同場面で起 こる 2 船間の相互影響についても考察を行う。

\section{2 先行研究 ${ }^{11}$ の概要}

以前に著者等は、深水域で並走する 2 船の舵と船 体の流体力学的干涉の基礎的な検討を行った。2 船 を並走させた水槽試験および理論計算の結果、例え ば進行方向に向かって右側の船 2 が右舵をとると、2 組の舵と船体という揚力体相互の流体力学的干渉に より、いずれの船体にも、2 船間内向き方向に付加 的な横力（揚力）が生じる事を明らかにした。左に 位置する船 1 が受ける付加横力の大きさは、狭い船 体間隔 $y_{0} / B=1.5$ (記号は次章を参照) の場合でも、 船 2 の舵力横方向成分の $5 \%$ 程度と必ずしも大きいと は言えなかったが、浅水域では変化する可能性があ り、調査が必要と思われる。

そこで本研究では同様の観点から、浅水域での舵 と船体の流体力学的干渉について検討を行う。

\section{2. 拘束模型試験の概要}

\section{1 浅水域用の仮床の設置}

広島大学曳航水槽内には 6 基の空気タンク式の昇 降台が設置してあり、その上に仮床を敷く事で浅水 域を実現できる。本研究では、Fig. 2.1 に示すよう な $18(\mathrm{~m}) \times 5(\mathrm{~m})$ の仮床を敷いた。水深 $h$ は、喫水 $d$ との比で $h / d=1.5$ と 1.2 に設定した。

\section{2 模型船主要目と計測項目}

供試船は、先行研究 ${ }^{1)}$ と同じく同型の Parabolic Wigley 船型である。2 隻を副電車の旋回装置に取 り付け、船体間隔、舵角および斜航角を種々変更し た試験を行った。2 船の運動は完全に拘束した状態 で実施した。船体と舵の主要目を Table 2.1 と 2.2 に、配置関係図を Fig. 2.2 に示す。また試験時の 様子をFig. 2.3 に示す。

各船体のミッドシップに 3 分力計を、舵位置に は舵検力計を取り付けて、前後力 $X$ (本論では議論 しない)、横力 $Y$ 、回頭モーメント $N$ および舵直圧 力 $F_{N}$ を計測した。ここで、 3 分力計で計測された
流体力には舵力成分が含まれている点に注意が必 要である。

計測結果は次式に基づき無次元化した。 $\rho$ は流体 密度、Uは船速であり、プライム記号が無次元值を 意味する。

$$
X^{\prime}, Y^{\prime}, F_{N}^{\prime}=\frac{X, Y, F_{N}}{(1 / 2) \rho L d U^{2}}, \quad N^{\prime}=\frac{N}{(1 / 2) \rho L^{2} d U^{2}}
$$

以後、進行方向に向かって左側の船を船 1 , 右側 を並走する船を船 2 と称し、各船の諸量は、船番号 を表す添字 $i(=1,2)$ を付けて区別する。

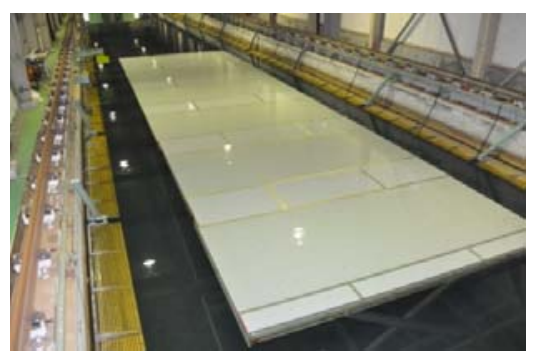

Fig.2.1 Scenery of shallow water area in Hiroshima University towing tank

Table 2.1 Principal dimensions of ship model

\begin{tabular}{|c|c|cc|}
\hline Length & $L$ & 1200 & $(\mathrm{~mm})$ \\
\hline Depth & $D$ & 200 & $(\mathrm{~mm})$ \\
\hline Breadth & $B$ & 120 & $(\mathrm{~mm})$ \\
\hline Draft & $d$ & 75 & $(\mathrm{~mm})$ \\
\hline Volume & $V$ & 0.0048 & $\left(\mathrm{~m}^{3}\right)$ \\
\hline Block Coefficient & $C_{b}$ & \multicolumn{2}{|c|}{0.444} \\
\hline
\end{tabular}

Table 2.2 Principal dimensions of rudder model

\begin{tabular}{|c|cc|}
\hline Wing section & \multicolumn{2}{|c|}{ NACA0020 } \\
\hline Chord length & 50 & $(\mathrm{~mm})$ \\
\hline Span length & 150 & $(\mathrm{~mm})$ \\
\hline Aspect ratio (Below W.L.) & \multicolumn{2}{|c|}{1.5} \\
\hline Gap between rudder and hull & 5 & $(\mathrm{~mm})$ \\
\hline
\end{tabular}

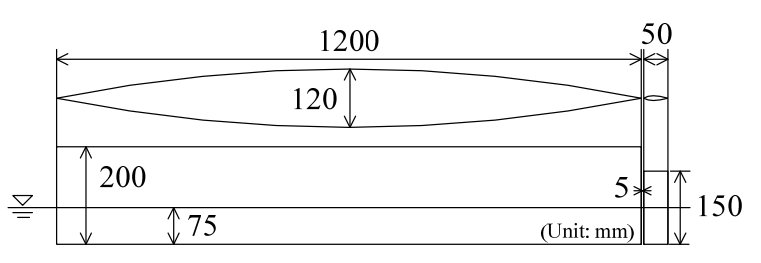

Fig.2.2 Arrangement of Wigley hull model with rudder

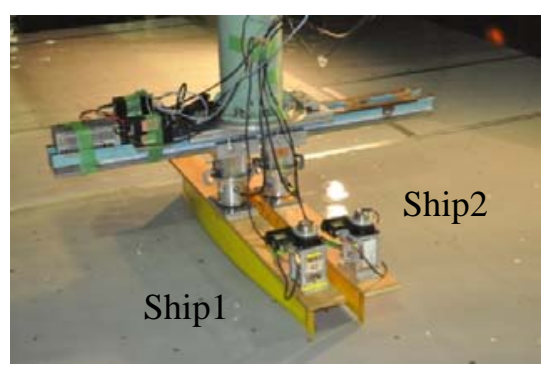

Fig.2.3 Photo of captive model test 


\section{3 実験条件}

フルード数 $F_{n}=0.1$ の船速で、舵角試験と斜航試験 を実施した。以下、各試験の詳細を述べる。

\section{3.1 舵角試験}

2 船を直進に並走させた状態で、進行方向に向か って右側の船 2 に、 $5^{\circ}$ 間隔で最大 $15^{\circ}$ まで一定舵 角を取らせた。船体間隔 (重心間距離) は、 $y_{0} / B=1.5$ 、 2.0、3.0の 3 パターンとした。

\section{3.2 斜航試験}

船 2 の斜航角を $5^{\circ}$ 間隔で、最大 $10^{\circ}$ まで変化さ せた。船体間隔は $y_{0} / B=2.17$ と 3.0 の 2 通りとした。 これは舵検力計を設置する都合上、 $y_{0} / B=2.17$ が斜航 試験時に設定可能な最小船体間隔であった事に因る。 本論では同船体間隔の結果のみを載せる。また試験 時の 2 船の舵角は共に 0 とした。

\section{3. 定式化および数值解法}

理想流体を仮定し、定常境界值問題を考える。船 体固定座標系をFig. 3.1 に示す。水深 $h$ の浅水域に、 船体と舵が斜航角 $\beta$ と舵角 $\delta$ を有して、船速相当の流 速 $U$ の一様流れの中に置かれているとする。船長方 向に $x$ 軸、幅方向に $y$ 軸をとり、 $x y$ 平面は静止水面 で剛体壁とみなした。

\section{1 流速の定義}

簡便な厚翼計算法の一つとして知られる $\mathrm{SQCM}^{6)} の$ 考え方に基づき定式化を行った。低速な為に造波を 無視すると、水面と水底という 2 つの剛壁に囲まれ た状況となる。そこでFig. 3.2 に図示される通り、 深さ方向に二重模型の無限鏡像を考慮する事で、同 流場をモデル化する。

まず任意の流場点 $P(x, y, z)$ における流速ベクトル を次のように定義する。

$$
\vec{V}(P)=(-U, 0,0)+\sum_{i}^{2}\left(\vec{V}_{S_{H}}^{(i)}+\vec{V}_{S_{R}}^{(i)}+\vec{V}_{C_{H}}^{(i)}+\vec{V}_{C_{R}}^{(i)}\right)
$$

総和記号内の第 1、2 項が、二重模型の船体表面 $S_{H}$ および舵表面 $S_{R}$ に配置する強さのの吹き出しによ る誘導速度を表し、次式で定義する。

$$
\vec{V}_{S_{H, R}}^{(i)}(P)=-\nabla \iint_{S_{H, R}^{(i)}} \sigma \sum_{l=-\infty}^{\infty} \frac{1}{r_{l}} d S
$$

ここで $l$ は二重模型の無限鏡像番号である (Fig. 3.2 参照)。各表面は矩形パネルに分割し、吹 き出し強さは各パネル上で一定とした。単位強さ当 たりの誘導速度はHess and Smith 法 ${ }^{7)}$ で計算する。 また $r_{l}$ は次のように書き表せる。

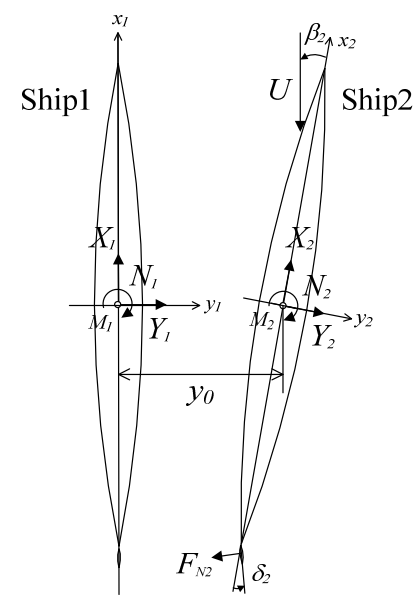

Fig.3.1 Ship fixed coordinate systems and definition of forces and moments, hull drift angle and rudder angle

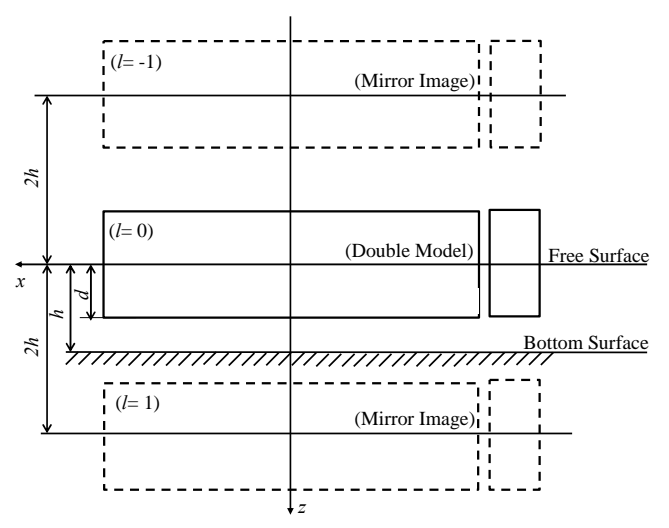

Fig.3.2 Sketch of infinite mirror images of the double model consisting of the hull and rudder

$$
r_{l}=\sqrt{(x-\xi)^{2}+(y-\eta)^{2}+\{z-(\zeta+2 h l)\}^{2}}
$$

ここで実像 $(l=0)$ の特異点位置を $Q(\xi, \eta, \zeta)$ とした。 続いて (3.1) 式の総和記号の第 3、4 項が、二重模型 の船体中心面 $C_{H}$ および舵キャンバー面 $C_{R}$ に配置す る馬蹄渦による誘導速度を表し、離散式は次のよう に書き表せる。

$$
\vec{V}_{C_{H, R}}^{(i)}(P)=\frac{\pi a}{2 N} \sum_{l=-\infty}^{\infty} \sum_{k=1}^{M} \sum_{m=1}^{N} \gamma_{k, m} \vec{v}_{\gamma_{l, k, m}} \sin \left\{\frac{(2 m-1) \pi}{2 N}\right\}
$$

$M 、 N$ は、 $C_{H, R}$ の深さ方向および長さ方向のパネ ル分割数である。また $a$ は船体中心面を分割する時 には船長を、舵キャンバー面の場合には舵のコード 長をとる。ベクトル $v_{\gamma_{l, k, m}}$ は鏡像 $l$ の $(k, m)$ 番目の馬蹄 渦（単位強さ）による誘導速度ベクトルを表し、1 本の束縛渦と一対の自由渦を構成する渦線分の誘導 速度ベクトルの和である。それらはBiot-Savartの 法則に従い計算される。そして $\gamma_{k, m}$ が馬蹄渦の強さ を表す。

なお舵への流入速度は、船体による粘性伴流の影 
響を受けて減少すると考えられる。ここでは船体軸 方向の舵流入速成分にの夕伴流率 0.3 (直進時) を仮 定した。後述の Fig. 4.2 で、舵直圧力の計算值と実 験值を比較するが、推定精度は悪くなく、設定した 值は概ね妥当と思われる。また斜航時には舵位置の 流速が回復する事を踏まえて、伴流率 $0.2(\beta= \pm$ $5,10 \mathrm{deg})$ を仮定し、その間の斜航角では線形補間し た值を用いた。

\section{2 境界値問題の定式化}

(3.1) 式は、剛壁の水面条件および水底条件を既 に満足している。そこで残りの境界条件の内、まず 物体表面を流れが貫かない条件を考える。

$$
\vec{V}(P) \cdot \overrightarrow{n_{S_{H, R}}^{(i)}}=0 \quad \text { P on } S_{H, R}^{(i)}
$$

ここでベクトル $n$ は各境界面の法線ベクトルを表 し、境界面から流体の内向きを正と定める。また別 途、船体中心面と舵キャンバー面を流れが貫かない 条件を考慮する。

$$
\vec{V}(P) \cdot \overrightarrow{n_{C_{H, R}}^{(i)}}=0 \quad \mathrm{P} \text { on } C_{H, R}^{(i)}
$$

(3.6) 式を課す長さ方向の標点位置は、Lan の $Q C M^{8)}$ に基づき、次のような式で与えられる。

$$
s_{C_{H, R_{j}}}^{(i)}=\frac{a}{2}\left\{1-\cos \left(\frac{j \pi}{N}\right)\right\} \quad(j=1,2,,, N)
$$

ここで $s$ は、船体中心面および舵キャンバー面上 の局所座標軸とし、船首端（舵前縁）を原点に船尾 (舵後縁) 方向を正とした。(3.7) 式より船尾端及び 舵後縁に標点が配置される事から、(3.6) 式を満たす 事で伴流に関する Kuttaの条件を満足できる。

以上より、（3.5）、（3.6）式の計８つの境界条件を 満足するように、吹き出しと馬蹄渦の強さを解く事 になる。そして船体・舵表面上の流速を決定後、流 体力は圧力積分により算出した。

\section{3 数值解法の概要}

\section{3.1 パネル分割数と鏡像数}

二重模型の船体表面を 20（深さ方向）×50（水線 方向）、舵表面を $20 \times 30$ 分割とし、各パネル内で一 定強さの吹き出しを配置した。船体中心面と舵キャ ンバー面には、それぞれ $20 \times 50(=M \times N)$ と $20 \times 30$ 個の束縛渦を置いた。

また鏡像数に関しては、深さ上下方向にそれぞれ 30 個の計 60 個の鏡像を考え、(3.2) と (3.4) 式の $l=$ \pm 30 で計算を打ち切った。Fig. 3.3 に、鏡像数を変 えて浅水域 $h / d=1.2$ の斜航計算（1隻）を行った結

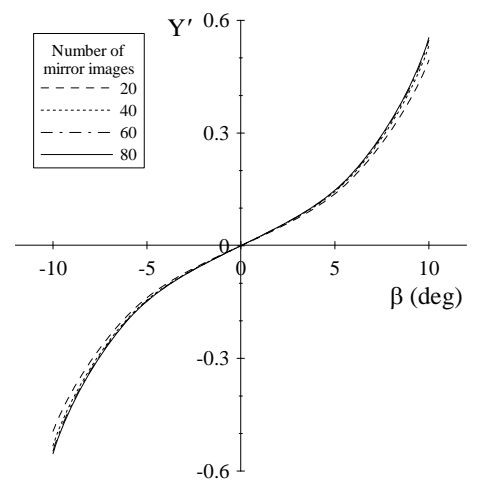

Fig.3.3 Dependence of the number of mirror images on the convergence of the lateral force $Y$ ' acting on a ship in oblique towing in shallow water i.e. $h / d=1.2$

果を示すが、60の鏡像数で横力無次元值 $Y$ ’が収束し ている事を確認できる。

\subsection{2 自由渦の流出角度}

斜航時、船体中心面の束縛渦を置いた位置から、 直ちに一定角度で無限遠方まで流出する自由渦を仮 定した。浅水域の場合、自由渦の流出角度 $\theta$ 深水 域と比べて大きくなる事が知られている。今回は安 $川^{9)}$ の補正にならい、 $h / d=1.5$ と 1.2 の浅水域におい て、それぞれ $\theta / \beta=0.69$ と 0.93 を設定した。深水域 は $\theta / \beta=0.5$ で計算を行った。一方、舵キャンバー面 上の束縛渦の位置から放出した自由渦は、船体の自 由渦と同方向へ後縁から流出させた。

また 2 船並走時は、船体間で流れの圧力が低くな る為、直進状態であっても自由渦は少なからず 2 船 の内側に角度を持って流出していると考えられる。 流出角が流体力に及ぼす影響は先行研究 ${ }^{1)}$ の付録で

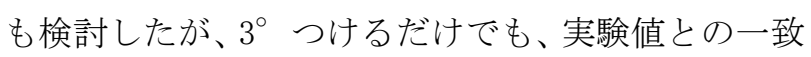
度が改善される傾向にあった。簡易的ではあるが、 ここでも一律 $3^{\circ}$ と仮定した。

\section{4. 結果と考察}

\section{1 吸引カとバウアウトモーメント}

舵角 $0^{\circ}$ の舵角試験結果に基づき、直進並走時の 吸引力とバウアウトモーメントを検討する。Fig. 4.1 に各船に作用寸る無次元化した横力 $Y_{i}{ }^{\prime}$ と回頭モー メント $N_{i}$ 'の絶対值を、水深喫水比の逆数 $d / h$ に対し て示す。ここで $d / h=0.02 、 0.67 、 0.83$ が、それぞれ 深水域 (水深 $h=3.5 \mathrm{~m}$ )、 $h / d=1.5$ 及び 1.2 に相当寸る。 実験点は、各船で計測された值の平均值をプロット してある。

深水域から水深が減少すると吸引力およびバウ アウトモーメントが徐々に大きくなる事が分かる。 そして水深が $h / d=1.5(d / h=0.67)$ より浅くなると、強 
い浅水影響を受けてバウアウトモーメントが急激に 増加する様子が見られ、計算結果もその傾向を捉え ている。一方、この時の吸引力の実験結果は同程度 もしくは若干減少するというものであり、計算結果 とは差が開いた。一つの理由として、h/d=1.2(同 $0.83)$ 程の浅水域では運動の履歴影響も強く複雑な 流場になっていたとも考えられ、今後の詳細な流場 計測やCFD による可視化が望まれる。

また 2 船の間隔が狭いほど、いずれの水深でも大 きな吸引力とバウアウトモーメントが作用した。
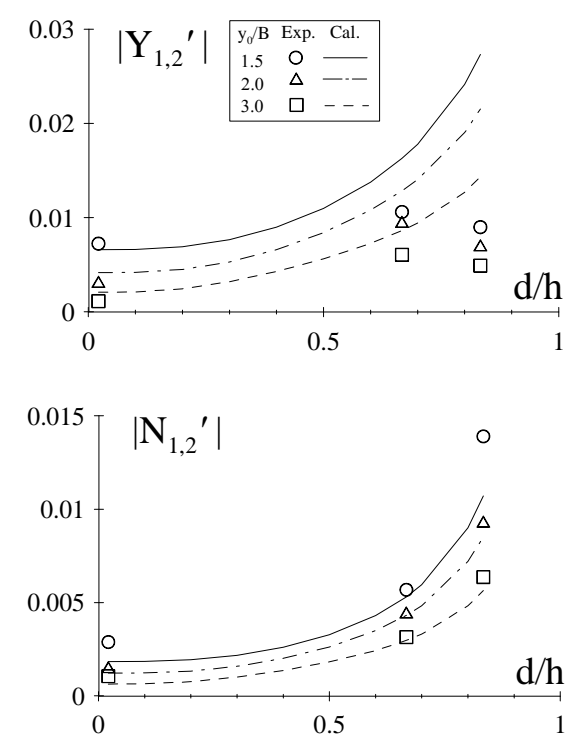

Fig.4.1 Steady suction force $\left|Y_{l, 2}\right|$ and bow-out moment $\mid N_{l, 2}$ ' acting on each ship alongside versus the $\mathrm{draft} / \mathrm{depth}$ ratio i.e. $d / h$

\section{2 舵角試験の結果}

\section{2.1 船 2 に作用する流体力}

浅水域で 2 船が並走した状況において、船 2 が舵 を取る時に、船 2 に作用する流体力を検討寸る。ま ず $y_{0} / B=1.5$ における舵角 $\delta_{2}$ と舵直圧力無次元值 $F_{N 2}$, の関係を Fig. 4.2 に示すが、後述の船体流体力 (Fig. 4.3) と比較して水深による差は大きくない。 一般に浅水域では水底に関する舵の鏡像効果の為に、 単独時の直圧力は増大寸ると思われる。しかし船体 背後に置かれた場合、舵と船体の相互干渉は舵力を 低下させる事が知られており ${ }^{10)}$ 、浅水域ではその効 果もまた強まるからと推測される。計算結果は、舵 直圧力勾配を実用上の精度で捉えている。

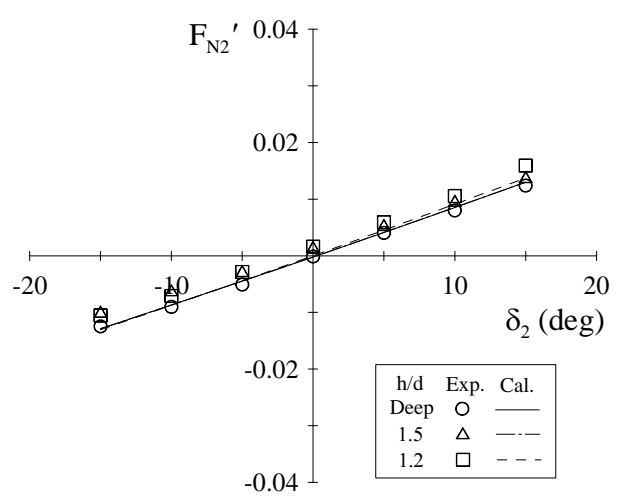

Fig.4.2 Rudder normal force $F_{N 2}$ 'of Ship2 versus rudder angle $\delta_{2}$ in the case of $y_{0} / B=1.5$

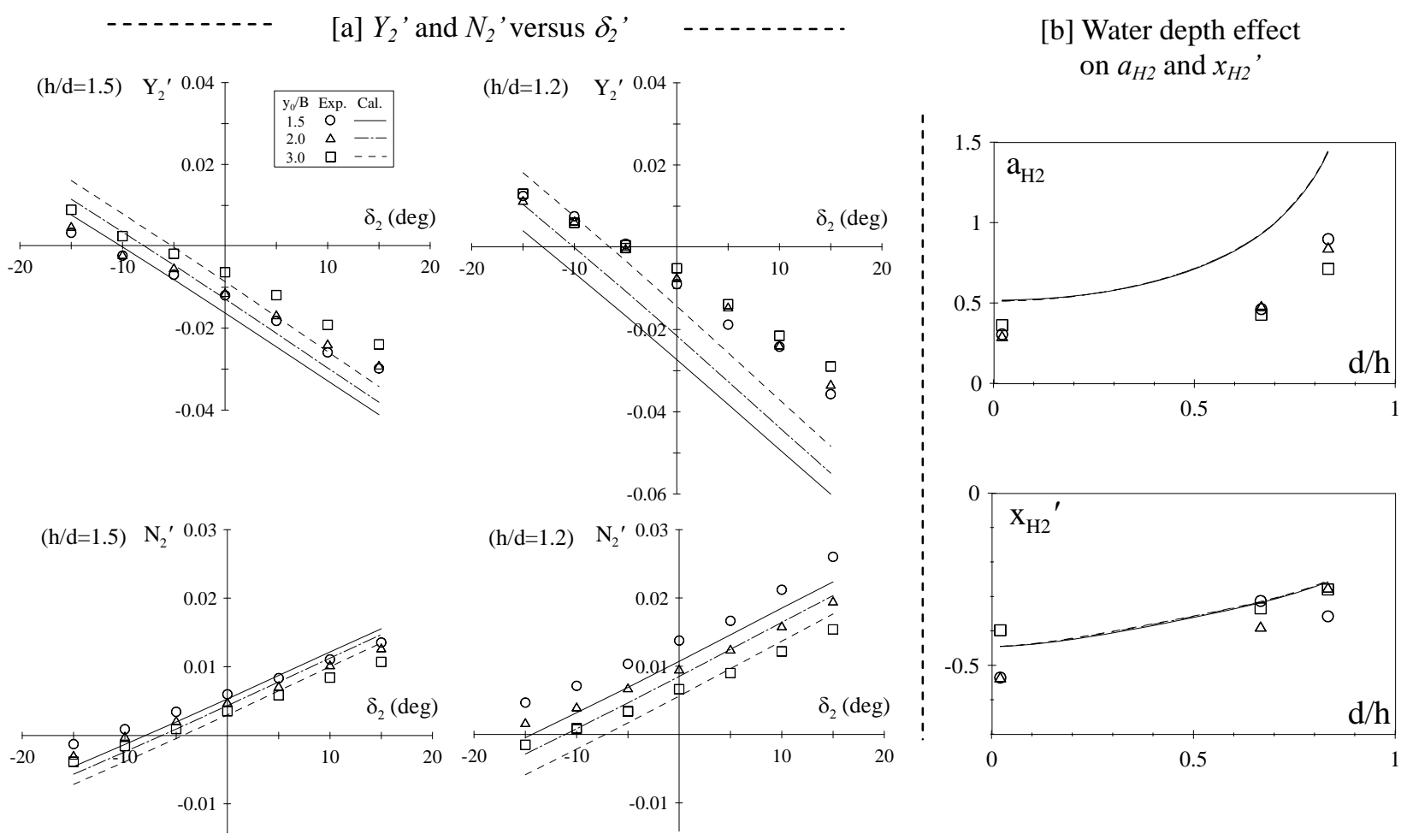

Fig.4.3: [a] Lateral force $Y_{2}$ 'and yawing moment $N_{2}$ 'acting on Ship2 due to Ship2 steering in the case of $h / d=1.5$ and 1.2. [b] Water depth effect on the interaction force parameters i.e. $a_{H 2}$ and $x_{H 2}$ ' 
続いて無次元化した横力 $Y_{2}$, とモーメント $N_{2}{ }^{\prime}$ の結 果をFig. 4. 3a に示す。実験結果に着目すると、船体 間隔に応じて、Fig.4.1 で図示した大きさの吸引力 （負の横力）とバウアウトモーメント（正のモーメ ント）が作用寸る為、 $Y_{2}{ }^{\prime}$ と $N_{2}{ }^{\prime}$ のプロット点全体が その分だけ縦軸方向にスライドしている。勾配は、 水深が浅いほど大きくなる様子が見られた。計算結 果は、特に $h / d=1.2$ での吸引力の差が $Y_{2}{ }^{\prime}$ のグラフ切 片の差として現れているが、 $Y_{2}{ }^{\prime}$ と $N_{2}{ }^{\prime}$ ともに定性的 な傾向は捉えている。

ここで操舵による流体力学的干渉について考察 する。MMG の考え方 ${ }^{11}$ を参考に、直進並走時、船 2 が舵を取る時に、船 2 に作用寸る横力と回頭モーメ ントの無次元値を次式で表現する。

$$
\begin{gathered}
Y_{2}^{\prime}=Y_{02}^{\prime}-\left(1+a_{H 2}\right) F_{N 2}^{\prime} \cos \delta_{2} \\
N_{2}^{\prime}=N_{02}^{\prime}-\left(x_{R}^{\prime}+a_{H 2} x_{H 2}^{\prime}\right) F_{N 2}^{\prime} \cos \delta_{2}
\end{gathered}
$$

右辺第 1 項は船体間の吸引力とバウアウトモーメ ントに関係し、解析上、例えば $Y_{02}{ }^{\prime}$ は、 $Y_{2}{ }^{\prime}$ を $F_{N 2}{ }^{\prime} \cos \delta_{2}$ に対して線形近似した際の切片とみなせる。そして 第 2 項が舵の寄与を表す。 $a_{H 2}$ は、操舵によって船 2 に誘起される横力成分の増加率であり、 $x_{H 2}{ }^{\prime}\left({ }^{\prime} x_{H 2} / L\right)$ は、その付加横力の船長方向着力点の無次元值を意 味している。 $x_{R}^{\prime}(=-0.5)$ は舵位置である。

これらの干涉係数を、 $d / h$ に対して Fig. $4.3 \mathrm{~b}$ に示 す。まず $a_{H 2}$ の実験結果は、水深が $h / d=1.5(d / h=0.67)$ より浅くなると急増しており、 $h / d=1.2$ (同 0.83) では船体間隔が狭いほど大きな值を示している。例 えば $y_{0} / B=1.5$ の場合、深水域の 2.94 倍の大きさと なった。計算結果は過大評価な傾向にあるが、水深 が浅くなると $a_{H 2}$ が急増する傾向は現れている。

次に着力点位置 $x_{H 2}$ 'に着目寸ると、実験結果より、 水深の減少に伴い船尾付近からミッドシップ方向へ 移動する事が分かる。船体間隔の影響に関しては、 明瞭な傾向は見られなかった。また計算結果は、水 深による $x_{H 2}{ }^{\prime}$ の変化を概ね再現できると思われる。

\section{2.2 船 1 に作用する流体力}

船 2 が舵を取る時に、並走する船 1 に作用する流 体力の無次元值を次式で表す。

$$
\begin{gathered}
Y_{1}^{\prime}=Y_{01}^{\prime}+a_{H 1} F_{N 2}^{\prime} \cos \delta_{2} \\
N_{1}^{\prime}=N_{01}^{\prime}+a_{H 1} x_{H 1}^{\prime} F_{N 2}^{\prime} \cos \delta_{2}
\end{gathered}
$$

右辺第 1 項は船体間の吸引力とバウアウトモーメ
ントに起因し、右辺第 2 項が、船 2 の操舵により船 1 に付加的に作用する横力とモーメントを意味する。 $a_{H 1}$ と $x_{H 1}$ ’゙、それぞれ船 2 の舵力横成分に対する割 合と、付加横力の着力点の無次元值を表している。

ここで船 2 の操舵による流体力学的干渉に焦点を 当てる為、舵角 $\delta_{2}$ に対する $Y_{1}{ }^{\prime}-Y_{01}$ 'と $N_{l}{ }^{\prime}-N_{01}{ }^{\prime}$ の結果 をFig. 4.4 と 4.5 に示す。各図において上段が実験 結果、下段が計算結果である。今回、模型船サイズ を大きくできず、計測された干渉力が比較的小さか った事から、実験点にバラつきがみられた。特に $\left[h / d=1.2, y_{0} / B=1.5, \delta_{2}=10,15^{\circ}\right]$ の計測值が十分な精 度になかったと判断し、以後の解析から外した。ま た傾向の把握を容易にするべく、実験結果には線形 近似直線を重㪍描いてある。

まず $Y_{1}^{\prime}-Y_{01}{ }^{\prime}$ の実験結果に着目する。深水域では近 似直線の傾きが正であり、船 2 の右舵 $\left(\delta_{2}>0\right)$ により 船 1 には吸引方向の付加横力が作用し、左舵 $\left(\delta_{2}<0\right)$ では反発方向に力が働く事が分かる。しかし水深が 浅くなると、その勾配が徐々に負へと変化し、力の 向きが逆転している。

一方、 $N_{I}{ }^{\prime}-N_{01}{ }^{\prime}$ の結果より、船 2 が右舵をとると船 1 にはバウアウトモーメントが作用し、左舵ではバ ウインモーメントを受ける事が分かる。また水深が 浅くなると、モーメントの向きは変化しないが勾配 は急となり、大きな干渉モーメントを受ける様子が うかがえる。定量值に差はあるが、水深に応じた一 連の傾向は、計算結果においても再現できている。

Fig. 4.6 に各干渉係数を $d / h$ に対してプロットし た。なお (4.4) 式より、解析上 $x_{H 1}$ 'は $a_{H 1}$ で除して求 める為、 $a_{H I}$ が 0 に近い場合は無限大となる点に注意 を要する。Fig. 4.4 から予想されたように、 $a_{H I}$ は深 水域において正の值をとるが、水深が浅くなると負 に転じている。 $y_{0} / B=1.5$ の場合、 $a_{H I}$ は深水域で 0.05 、 浅水域 $h / d=1.2(d / h=0.83)$ では-0.065 であり、そ れぞれ船 2 の舵力横成分の $5.0 \%$ と $6.5 \%$ の大きさの付 加横力が作用する事が分かる。また計算結果を基に 検討すると、 $a_{H I}$ は、船体間隔が狭いほど水深変化に 伴う変化の幅が大きいと思われる。一方、 $x_{H 1}$ 'の結 果より、深水域ではミッドシップ後方にあった着力 点が、浅水域では前方に移動する様子がうかがえる。

続いて、干渉流体力がこのように水深に応じて複 雑に変化する背景を考察する。Fig. 4.7 に、各水深 において $y_{0} / B=1.5$ の船体間隔で船 2 が $15^{\circ}$ の右舵を 取った時の両船体中心面上の渦強さ $\gamma$ のンター図 を描いた。ここで $\gamma>0$ が反時計回りの渦分布を意味 

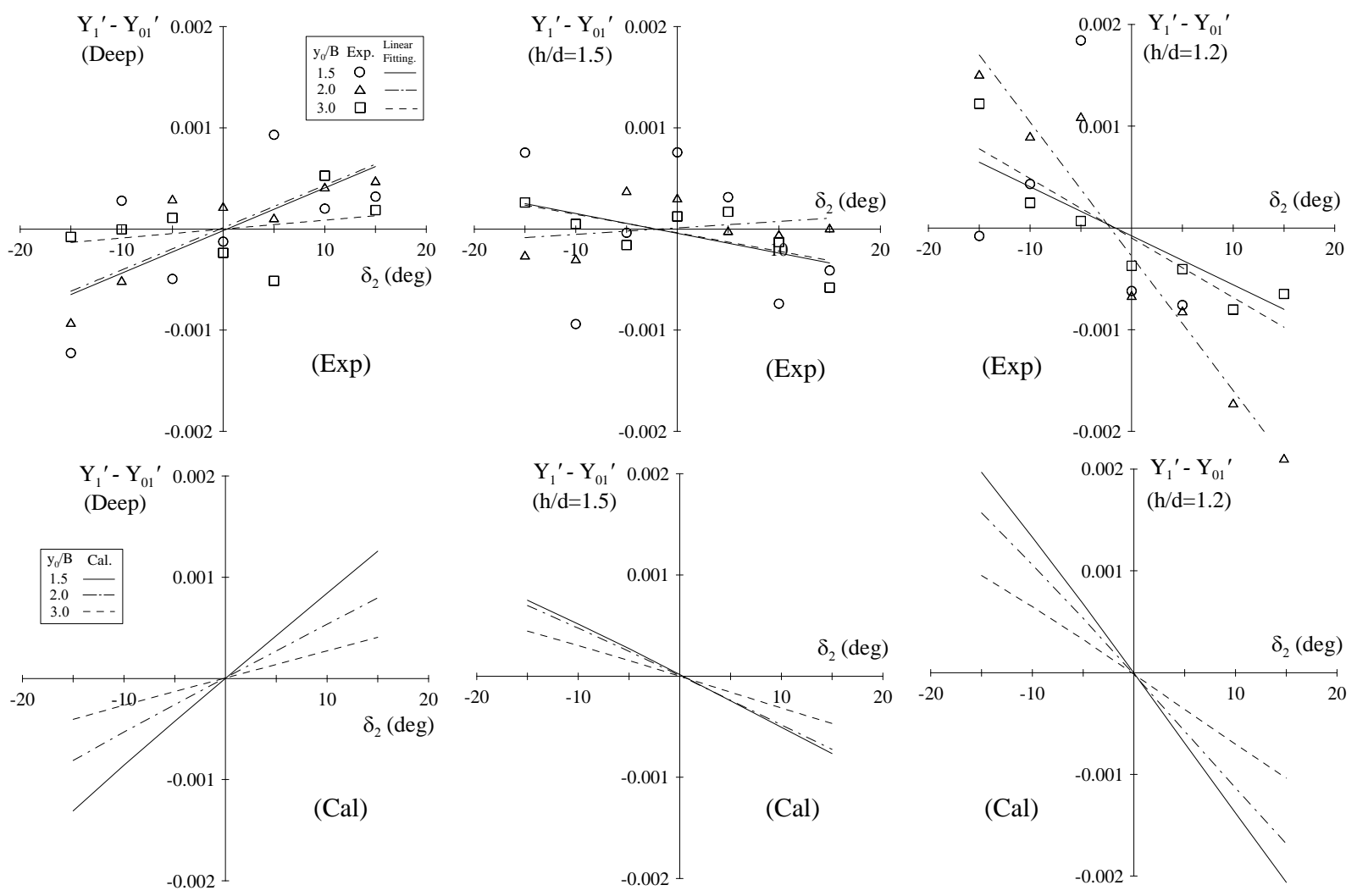

Fig.4.4: Additional lateral force $Y_{1}^{\prime}$ - $Y_{01}$ ' acting on Ship1 due to Ship2 steering in deep water and shallow water i.e. $h / d=1.5$ and 1.2. Experimental values are plotted with the fitting lines on the above figures and calculated results are shown on below them
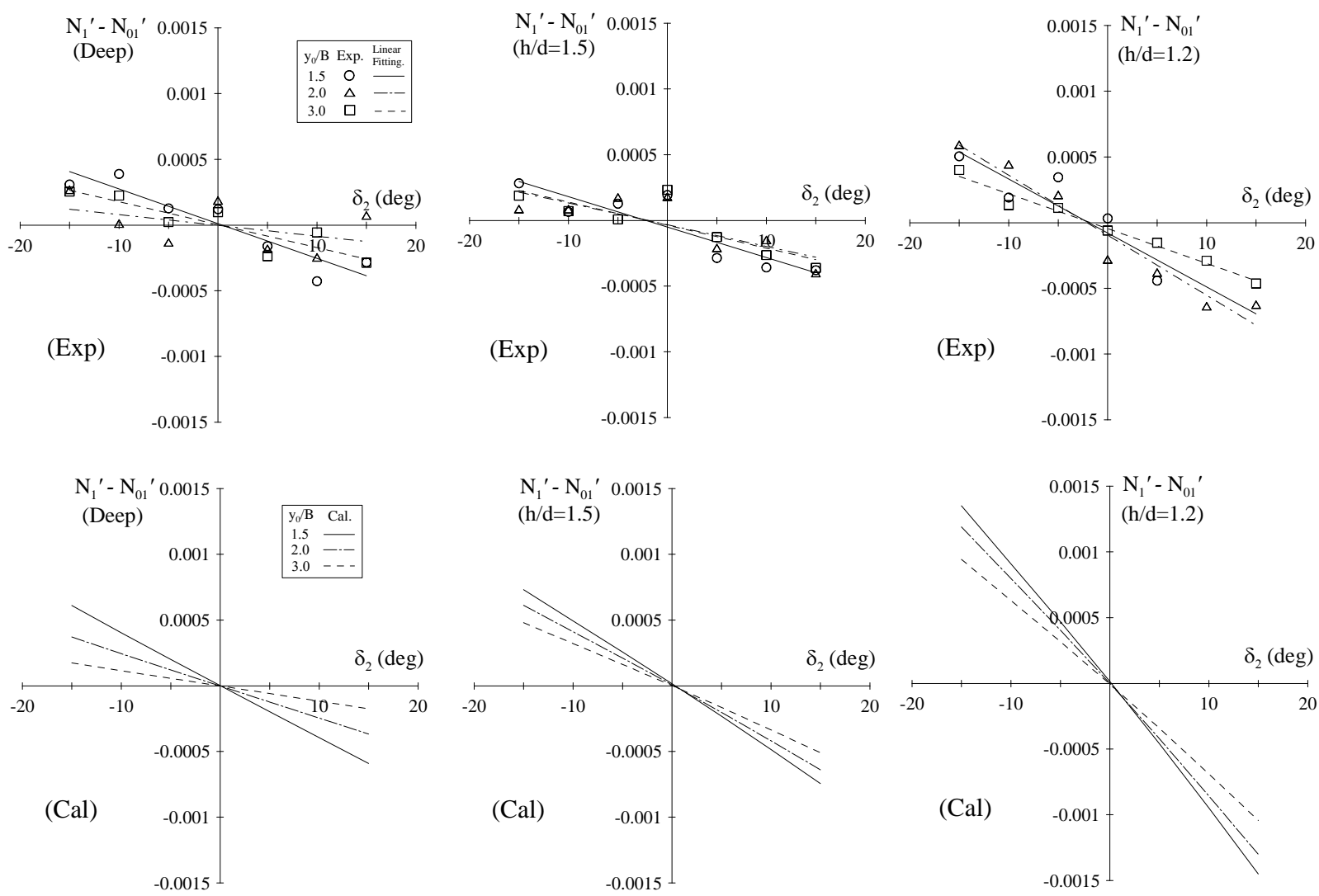

Fig.4.5: Additional yawing moment $N_{l}{ }^{\prime}-N_{01}$ ' acting on Ship1 due to Ship2 steering in deep water and shallow water i.e. $h / d=1.5$ and 1.2. Experimental values are plotted with the fitting lines on the above figures and calculated results are shown on below them 

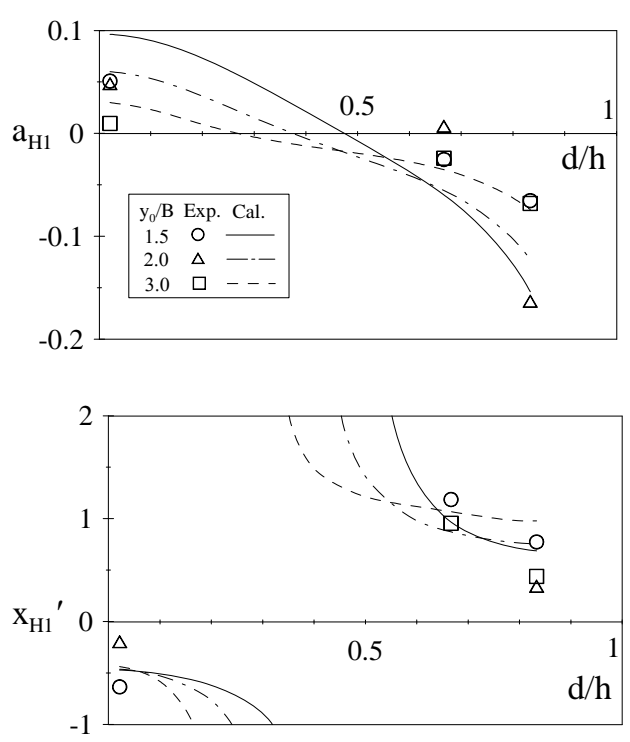

Fig.4.6: Water depth effect on the interaction force parameters i.e. $a_{H 1}$ and $x_{H I}$,

する。なおコンター図は $\mathrm{QCM} \mathrm{P}^{8}$ による計算結果とした。 QCM では船体、舵の厚みを扱わず、舵角ゼロの直進 状態であれば 2 船並走時でも渦は生じない。この為、 舵を取ると誘起される渦の強さをゼロからの変化と して捉えられ、理解が容易であった事がその理由で ある。

船体中心面に分布する渦の回転方向（の符号）に 着目すると、まず深水域では、右に位置する船 2 が 右舵をきる場合、船 2 の船体には反時計回りの渦分 布（ $\gamma>0 ）$ 、寸なわち反時計回りの循環が作用し、船 1 の船体には、時計回りの循環が作用する様子がう かがえる。つまり互いを引き寄せ合う方向に付加横 力（揚力）が作用寸る。一方、浅水域では、船尾付 近に深水域と同方向の渦分布がそれぞれ誘起される 点は同じであるが、船 $1 、 2$ 共に船首付近に反時計回 りの強い渦分布が見られた。この傾向は水深が浅い ほど顕著であり、浅水域になると 2 船のみならず鏡 像翼を含めた複数翼間で複雑な流体力学的干渉が起 こるからと思われる。船 1 の場合は、結果的に周方 向の流速を積分して得られる循環が反時計回りとな り、遂には付加横力が反発方向に転じたものと推測 される。

\section{3 斜航試験の結果}

\section{3.1 船 2 に作用する流体力}

2 船間隔が $y_{0} / B=2.17$ の状況で船 2 が斜航する時に、 船 2 に作用する流体力の無次元值 $Y_{2}$ 'と $N_{2}$ 'を Fig. 4.8 に示す。横軸は斜航角 $\beta_{2}$ である。

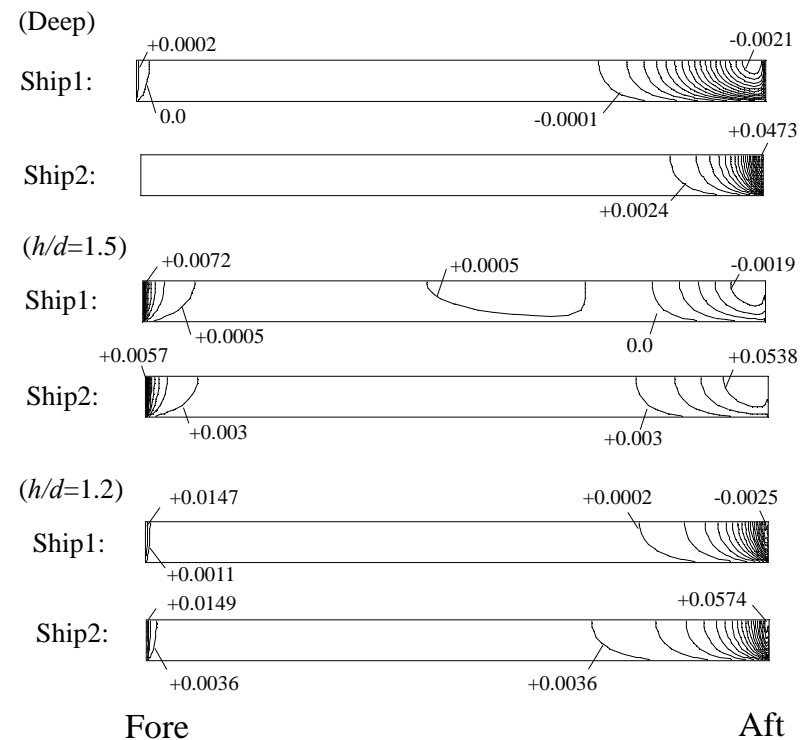

Fig.4.7: Contour lines of the strength of bound vortexes distributed over the hull center plane $\left(y_{0} / B=1.5, \delta_{2}=+15^{\circ}\right)$

まず実験結果に着目する。水深が浅いほど $Y_{2}{ }^{\prime}$ の大 きさが増加しており、典型的な浅水影響が見られる。 $h / d=1.2$ の浅水域では、左右の斜航時で横力に若干 の差が現れているが、総じて傍を並走する船 1 が船 2 の斜航横力に及ぼす影響は小さいといえる。

一方、回頭モーメント $N_{2}{ }^{\prime}$ は、船 2 の船尾が船 1 側に近づく場合 $\left(\beta_{2}>0\right)$ に、より大きな值を示した。 これはバウアウト方向のモーメントであり、2 船の 船尾を更に接近させる方向である事から、衝突の恐 れがある危険な状態といえる。同傾向は水深が浅く なるほど顕著に現れており、浅水域において並走す る船 1 の影響が強まる様子がうかがえる。

\section{3.2 船 1 に作用する流体力}

前節の船 2 が斜航する状況下で、並走する船 1 に 作用する流体力 $Y_{1}$ 'と $N_{l}$ 'を Fig. 4.9 に示す。横軸は 船 2 の斜航角 $\beta_{2}$ である。実験結果より、船 2 の船首 が船 1 側に回頭すると $\left(\beta_{2}<0\right)$ 、吸引力 $\left(Y_{I}{ }^{\prime}>0\right)$ が 増大寸る事が分かる。その勾配は、 $h / d=1.5$ より浅 くなると急激に大きくなっている。一方、船 2 の船 首が船 1 の逆側に回頭する場合 $\left(\beta_{2}>0\right)$ 、その斜航角 の増加と伴に船 1 に働く吸引力は減少し、反発力一 転じている。特に $h / d=1.2$ の浅水域において、大き な反発力が働く様子がうかがえる。

また $N_{l}$ に関して、 $\beta_{2}<0$ の場合、 $h / d=1.2$ の浅水 域では、吸引力 $Y_{I}$ 'の増加に呼応してバウアウトモー メント $\left(N_{I}{ }^{\prime}<0\right)$ の増加が見られた。一方、 $\beta_{2}=10^{\circ}$ において、船 1 は上述通り反発力を受けるようにな るが、回頭モーメントは水深に依らずバウアウト方 向に作用している。これは斜航する船 2 の影響を受 
けて、着力点の位置がミッドシップ前方にシフトし たからと推測される。

なお一連の計算結果は、浅水影響ならびに 2 船間 の流体力学的干渉を受けた各船の流体力の傾向を、 概ね説明できる事が分かる。

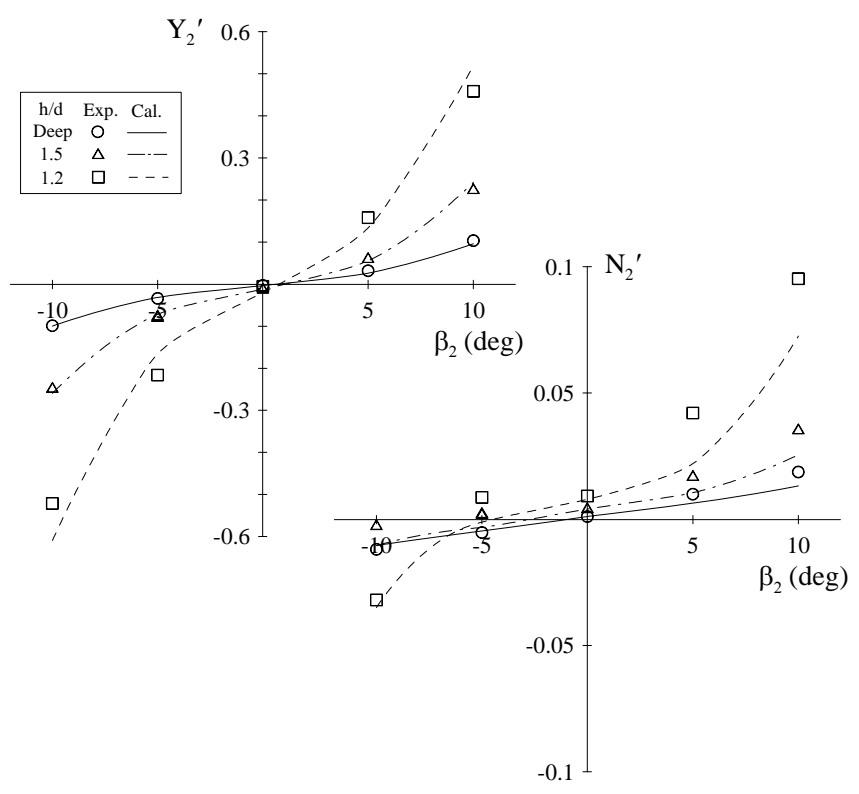

Fig.4.8: Lateral force $Y_{2}$ ' and yawing moment $N_{2}$ ' acting on Ship2 in oblique towing of Ship2 $\left(y_{0} / B=2.17\right)$

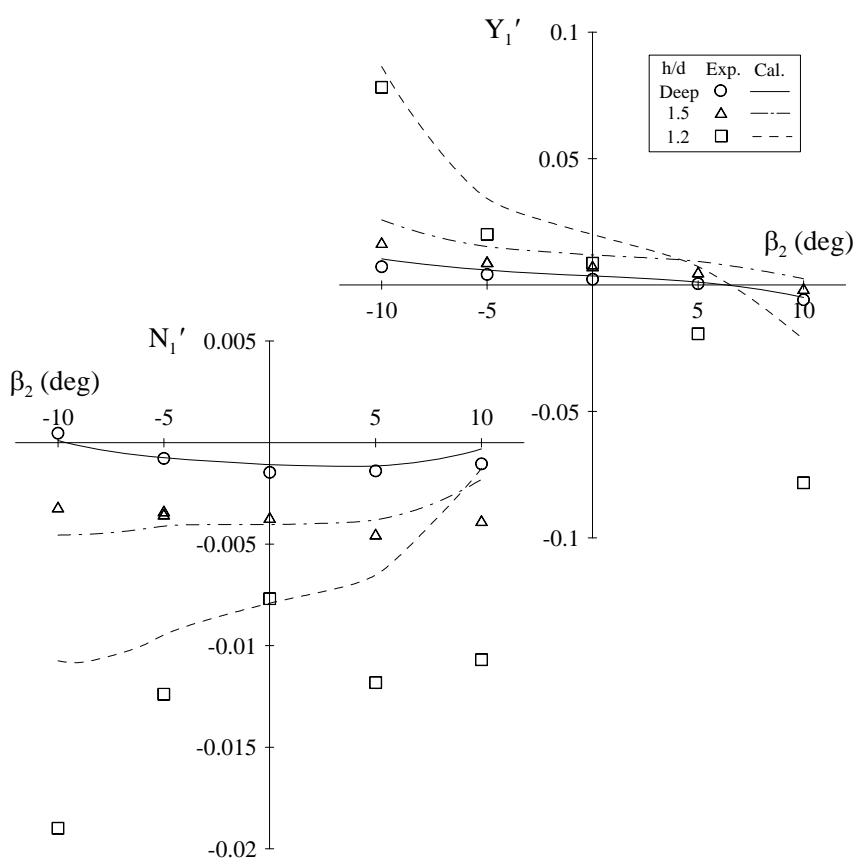

Fig.4.9: Lateral force $Y_{l}$ ' and yawing moment $N_{l}$ ' acting on Ship1 in oblique towing of Ship2 $\left(y_{0} / B=2.17\right)$

\section{5. 結言}

2 隻の船が並走する状況は緊張局面の一つである が、その場合の舵と船体の流体力学的干渉は明らか

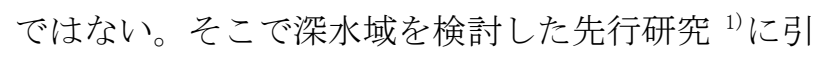

き続き、浅水域で実験を行い、同干渉に及ぼす浅水 影響について基礎的な検討を行った。今回得られた 主な知見をまとめる。

a）水深が減少すると、舵を取る事で自船の船体に 作用する付加的な横力は増大寸る。船体間隔の 影響は $h / d=1.5$ より浅くなると明瞭に現れ、船 体間隔が狭い程、大きな付加横力が働く。

b）並走状態で片方の船が舵を取ると、他方の船（他 船）もまた付加的な横力を受ける。その向きは 水深に応じて変化し、例えば進行方向右に位置 する船が右舵をとる場合、深水域では他船に吸 引方向の付加横力が作用寸るが、水深の減少と 伴に向きが逆転する。一方、他船に働く付加横 力の着力点はミッドシップを跨いでシフトする と思われ、それによる付加回頭モーメントの向 きに変化は無い。

c）舵を取る船の舵力横成分に対して、他船が受け る付加横力の大きさ（絶対值）は、船体間隔 $y_{0} / B=1.5$ の場合、深水域で約 $5 \%$ 、浅水域 $h / d=1.2$ でも $6.5 \%$ 程度であった。この為、項目 (a) とは 異なり、他船に働く付加横力の大きさが、浅水 域で顕著に増加する事は無いと思われる。

続いて並走時に 1 隻が斜航する状況で実験を行い、 次の知見を得た。

d）並走状態で一方の船がバウアウト側に斜航する 時、逆斜航時と比較して、その船にはより大き な回頭モーメントが作用寸る。同状況下では他 方の船にも、バウアウトモーメントが作用する。 それらの大きさは、水深が浅いほど大きい。

また本研究では併せて理論計算結果を示し、現象 のメカニズムを考察した。特に項目 (b) で述べた他船 が受ける付加横力の水深に応じたユニークな変化の 傾向を捉えた一方、定量的な精度には課題を残した。 各船体から流出される自由渦の流出角は、傍を並走 する船の影響を受ける可能性がある。この為、一つ の改善策としては、湯室 ${ }^{12)}$ のように渦強さに加え流 出角をも未知数として扱い、反復法により解く方法 が考えられる。引き続き、精度改善を検討したい。

\section{謝辞}

本研究の一部は、日本学術振興会科学研究費補助 金 (若手研究 (B)：24760676) の助成を受けて行われ た。ここに記して関係者各位に謝意を表します。 


\section{参考文献}

（1）佐野将昭・安川宏紀・吉田聖子：操舵しながら 近接航行する 2 船の流体干渉に関する基礎研究, 日本船舶海洋工学会論文集, 第 16 号, pp. 59-67, 2012.

(2) Tuck, E. 0. and Newman, J. N. : Hydrodynamic interactions between ships, Proc. 10th Symp. on Naval Hydrodynamics, Cambridge, pp. 35-70, 1974.

(3) Vantorre, M., Verzhbitskaya, E. and Laforce, E. : Model test based formulations of shipship interaction forces, Ship Technology Research, Vol.49, pp. 124-140, 2002.

（4）湯室彰規：操縦流体力における 2 船間干渉に関 寸る近似計算, 関西造船協会誌, 第 212 号, 1989, pp. 113-121.

（5）藤野正隆 - 加納敏幸 - 元良誠三 : 舵と船体の相 互干渉に関寸る基礎的研究 (第 2 報), 日本造船 学会論文集，第 147 号, pp. 136-143， 1980.

（6）中武一明・安東潤・片岡克己・吉武朗 : 簡便な 一厚翼計算法, 西部造船会々報, 第 88 号, pp. 13-21, 1994.

(7) Hess, J. L. and Smith, A. M. 0. : Calculation of nonlifting potential flow about arbitrary three dimensional bodies, Journal of Ship Research, Vo1.8, No. 2, pp. 22-44, 1964.

(8) Lan, C.E. : A Quasi-Vortex-Lattice Method in Thin Wing Theory, Journal of Aircraft, Vol. 11, No. 9, pp. 518-527, 1974.

(9) H. Yasukawa : Shallow water effects on hydrodynamic characteristics of a turning thin ship, 西部造船会々報, 第 85 号, pp. 57-69, 1993.

（10）藤野正隆 - 沼田敏晴 - 元良誠三 : 舵と船体 の相互干涉に関する基礎的研究, 日本造船学会 論文集，第 146 号，pp. 213-221，1979.

（11） 小瀬邦治・湯室彰規・芳村康男：III. 操縦 運動の数学モデルの具体化一船体・プロペラ・ 舵の相互干渉とその表現, 第 3 回操縦性シンポ ジウム, pp. 27-80, 1981.

（12）湯室彰規: 斜行平板の自由渦流出角に及ぼ 寸側壁影響, 関西造船協会誌, 第 232 号, pp. 47-53, 1999. 